\title{
Ants (Hymenoptera: Formicidae) Collected with Carrion-Baited Traps in Southeast Brazil
}

\author{
Thiago de Carvalho Moretti ${ }^{*}$, , Daniel Russ Solis ${ }^{2}$ and Wesley Augusto Conde Godoy ${ }^{2}$ \\ ${ }^{I}$ Departamento de Biologia, Faculdade de Filosofia, Ciências e Letras de Ribeirão Preto, Universidade de São Paulo, \\ 14040-901, Ribeirão Preto, São Paulo, Brazil \\ ${ }^{2}$ Departamento de Entomologia e Acarologia, Escola Superior de Agricultura Luiz de Queiroz, Universidade de São \\ Paulo, 13418-900, Piracicaba, São Paulo, Brazil
}

\begin{abstract}
Ants can both feed on vertebrate carrion and prey upon other arthropods inhabiting corpses. An investigation using carrion-baited traps was conducted in three environments (rural, urban, and forest) in six municipalities of southeast Brazil, from September 2006 to October 2007. We collected 113 specimens of ants from the subfamilies Dolichoderinae, Myrmicinae and Formicinae. Bait and environmental associations of ants and potential forensic implications of their actions are discussed.
\end{abstract}

Keywords: Camponotus, Cephalotes, Dolichoderus, Forensic entomology, Necrophagy.

\section{INTRODUCTION}

Although Diptera and Coleoptera are by far the most important orders in medico-legal entomology, other insect orders (e.g., Lepidoptera, Hemiptera, Blattodea, Dermaptera, and Hymenoptera) and other arthropod groups (e.g., Acari, Araneae, Opiliones, Chilopoda, Diplopoda) are frequently found in association with cadavers, and are therefore to be considered of potential interest in forensic analyses [1,2]. These neglected taxa are not commonly used in research with cadaveric fauna, and usually biological and behavioral information is insufficient to allow a definite decision regarding their inclusion or exclusion from the range of useful decomposing arthropods. The literature commonly contains only brief new records of specimens from these orders found on carcasses, with no attempt to investigate their role in the decomposition event [2].

The relationships of ants with carrion range from direct feeding on the carcass (necrophagy), to predation on other arthropods associated with the corpse [3]. As necrophages, besides their role in consuming dead flesh, ants can also produce abrasions or injuries that can attract other species of necrophagous insects, thus speeding up the decomposition process. Moreover, these lesions can be interpreted as premortem mutilations, which can lead to major errors in forensic analyses $[4,5]$. As predators, ants may basically display 5 types of behavior that may affect the pace of the decomposition process, the normal succession of insects on the carcasses, and therefore the estimation of the minimum postmortem interval, as follows: (i) preying upon other adult

*Address correspondence to this author at the Departamento de Biologia, Faculdade de Filosofia, Ciências e Letras de Ribeirão Preto, Universidade de São Paulo. Av. Bandeirantes, 3900, Monte Alegre, 14040-901, Ribeirão Preto, São Paulo, Brazil; Tel: +55-16-3602-4445;

Fax:+55-16-3602-4886; E-mail: tcmoretti@yahoo.com.br arthropods associated with carrion; (ii) carrying away insect eggs; (iii) removal of maggots of carrion flies (mainly calliphorid and sarcophagid flies) from the carcasses; (iv) the recently described burying of wounds of corpses (i.e. ants filling in the lesion with soil), with the consequent exclusion of necrophagous arthropods from these wounds; and (v) increasing the gaps in the occurrence matrix of necrophagous insects in the corpses [4, 6-9].

Ants are found during the entire decay process [10], and are much more important in carrion decomposition in tropical than in temperate environments [4]. The forensic importance of ants is still not usually appreciated by crimescene analysts and forensic pathologists [4], which motivated us to report the presence of this group of insects attracted to 3 types of vertebrate carrion in environments with different levels of urbanization in São Paulo State, southeast Brazil.

\section{MATERIALS AND METHODOLOGY}

\section{Study Sites}

The collections were carried out in rural, urban, and forest environments in six municipalities in São Paulo State, southeast Brazil: Artur Nogueira (S 22 $34^{\prime} 22^{\prime \prime}$ W $47^{\circ} 10^{\prime}$ 22"), Campinas (S 22 $\left.53^{\prime} 20^{\prime \prime} \mathrm{W} 47^{\circ} 04^{\prime} 40^{\prime \prime}\right)$, Cosmópolis (S $\left.22^{\circ} 38^{\prime} 45^{\prime \prime} \mathrm{W} 47^{\circ} 11^{\prime} 46^{\prime \prime}\right)$, Jundiaí (S 23 $11^{\prime} 11^{\prime \prime} \mathrm{W} 46^{\circ}$ 53' 03"), Mogi Guaçu (S $22^{\circ} 22^{\prime} 20^{\prime \prime} \mathrm{W} 46^{\circ} 56^{\prime} 32^{\prime \prime}$ ) and Paulínia (S $\left.22^{\circ} 45^{\prime} 40^{\prime \prime} \mathrm{W} 47^{\circ} 09^{\prime} 15^{\prime \prime}\right)$.

The rural areas in these municipalities are characterized by moderate agricultural activity and livestock farming, with a few scattered houses; the urban sites have modest commercial activity; and the forest sites are mainly woodland remnant patches with similar phytophysiognomic features, with the exception of Campinas, where the forest area is a 250-ha mesophilic semideciduous Atlantic Forest fragment [11] surrounded by human dwellings [5]. 
All these municipalities have a subtropical climate, with a dry season with mild temperatures (winter; mid-Jun to Aug) and a warm rainy season (summer; mid-Nov to Mar). The two intermediate seasons, autumn (Apr-May) and spring (Sep-Nov), are characterized by fluctuations in temperature and rainfall [12].

\section{On-Site and Laboratory Procedures}

The collections were made monthly from Sep 2006 to Oct 2007. Each of the environments in each municipality was monitored using 6 traps per month, 2 for each kind of bait, totaling 18 traps per municipality/month and 1,512 sample units during the study. Baits composed of $12 \mathrm{~g}$ of one of the following: fish (sardines), beef liver, or chicken gizzards were employed, after being left to rot for about $48 \mathrm{~h}$ at room temperature. Carrion traps were installed approximately $15 \mathrm{~m}$ apart at the collection sites. Each trap was made of two 2.0-liter plastic soft-drink bottles, each approximately $30 \mathrm{~cm}$ in height and $10 \mathrm{~cm}$ in diameter. The bottoms of both bottles were removed to allow one to fit into the other and to permit the entrance of insects through the bottom opening of the lower bottle, which was painted black. The cap of the lower bottle was also removed, so its top end was open. Each bait was placed at the top end of the lower bottle with a small metal hook, and was replaced in the traps every $24 \mathrm{~h}$ (the design of the carrion trap was described by Moretti et al. [5].

Each trap was suspended with a cord from a tree branch, approximately $180 \mathrm{~cm}$ above the ground. The trap remained exposed at the study site for a period of $72 \mathrm{~h}$, after which all insects trapped in the top bottle were collected, taken to the laboratory, and killed by freezing at $-20{ }^{\circ} \mathrm{C}$, until later identification. The ants were identified according to Bolton [13]. After identification, the specimens were stored in a freezer.

\section{RESULTS}

We collected specimens of Dolichoderus Lund and Azteca Forel (Dolichoderinae), Crematogaster Lund, Pheidole Westwood, Solenopsis Westwood, Cephalotes Wheeler, and Cephalotes clypeatus F. (Myrmicinae), and 5 morphospecies of Camponotus Mayr (Formicinae), totaling 113 specimens of ants. Table 1 shows the distribution of the specimens according to the type of bait and environment. Most ants were attracted to chicken gizzards (44.2\%), followed by beef liver (37.2\%) and fish (18.6\%). Most specimens were collected in the forest $(66.4 \%)$, followed by the rural $(20.3 \%)$ and urban environments (13.3\%).

The ants were observed feeding on the baits and their exudates, and preying upon adult insects collected in the traps (mainly blow flies and flesh flies). We also could see ants collecting blow fly maggots (possibly first-instars) in the very rare instances when oviposition/larviposition took place on the baits in spite of the brief period available for this. The ants gained access to the traps by crawling down the hanging cord. Only fragments of these predated insects, which proved inadequate to allow their identification to species level, were regularly found in the traps from which ants were collected.

Table 1. Ants Collected in Southeast Brazil: Abundance per Type of Bait, and their Association with Different Microenvironments

\begin{tabular}{|c|c|c|c|c|c|c|c|c|c|}
\hline \multirow{3}{*}{ Taxon } & \multicolumn{9}{|c|}{ Baits/Environment } \\
\hline & \multicolumn{3}{|c|}{ Fish } & \multicolumn{3}{|c|}{ Beef Liver } & \multicolumn{3}{|c|}{ Chicken Gizzards } \\
\hline & $\mathbf{R}$ & $\mathbf{U}$ & $\mathbf{F}$ & $\mathbf{R}$ & $\mathbf{U}$ & $\mathbf{F}$ & $\mathbf{R}$ & $\mathbf{U}$ & $\mathbf{F}$ \\
\hline \multicolumn{10}{|l|}{ Formicinae } \\
\hline Camponotus sp.1 $(\mathrm{n}=7)$ & 1 & - & - & - & 2 & - & 2 & 2 & - \\
\hline Camponotus sp.2 $(\mathrm{n}=5)$ & - & - & - & - & - & - & 5 & - & - \\
\hline Camponotus sp.3 $(\mathrm{n}=3)$ & - & - & 1 & - & - & - & 2 & - & - \\
\hline Camponotus sp.4 $(\mathrm{n}=2)$ & - & - & - & - & - & 2 & - & - & - \\
\hline Camponotus sp.5 $(\mathrm{n}=1)$ & - & - & - & - & - & 1 & - & - & - \\
\hline \multicolumn{10}{|l|}{ Myrmicinae } \\
\hline Cephalotes sp. $(\mathrm{n}=12)$ & - & - & - & - & - & 9 & - & - & 3 \\
\hline C. clypeatus $(\mathrm{n}=6)$ & - & - & - & - & - & 1 & - & 3 & 2 \\
\hline Crematogaster sp. $(\mathrm{n}=8)$ & - & - & - & 3 & - & - & - & 5 & - \\
\hline Pheidole sp. $(\mathrm{n}=4)$ & - & - & 1 & - & - & - & - & - & 3 \\
\hline Solenopsis sp. $(\mathrm{n}=4)$ & - & - & - & - & - & - & 4 & - & - \\
\hline \multicolumn{10}{|l|}{ Dolichoderinae } \\
\hline Azteca $\mathrm{sp} .(\mathrm{n}=2)^{1}$ & - & - & - & - & - & 2 & - & - & - \\
\hline Dolichoderus sp. $(\mathrm{n}=59)^{1}$ & - & - & 18 & - & - & 22 & 6 & 3 & 10 \\
\hline TOTAL $(n=113)$ & 1 & 0 & 20 & 3 & 2 & 37 & 19 & 13 & 18 \\
\hline
\end{tabular}

(R) rural; (U) urban; (F) forest.

${ }^{1}$ First reported occurrence on vertebrate carrion in the Neotropical region. 


\section{DISCUSSION}

Hymenopterans are a particularly challenging group from the taxonomic identification standpoint [14]. As a result, many specimens collected in the present study remained identified as morphospecies rather than taxonomic species (Table 1). Despite recent efforts made to facilitate the identification of Neotropical ants, e.g., revisions of problematic genera and the development of image databanks and electronic keys, species identification is still a complex task for some genera, such as Camponotus (Formicinae), Crematogaster, Pheidole, and Solenopsis (Myrmicinae) [15]. The recognition of morphospecies is then a necessary component of surveys of Neotropical ants [16].

Comparing the species of ants collected in the present study with those reported in other peer-reviewed publications and books on carrion ants in the Neotropical region, we found that several species of Camponotus, Crematogaster, Pheidole, and Solenopsis were collected in various habitats and from different types of carcasses [17]. In contrast, we found no records for the two genera of Dolichoderinae that we collected. Thus, to our knowledge this is the first formal record of Azteca and Dolichoderus found on vertebrate carrion in the Neotropical region.

There is no consensus about the nutritional biology of members of Dolichoderinae. Cook and Davidson [18] stated that these ants feed on carbohydrate-rich liquids, such as plant exudates, honey, or honeydew. We presume that in general, ants of this subfamily may be attracted to carrion to feed on the hemolymph of insects trapped in the bottles or on the exudates from carrion.

Cabrera and Jaffé [19] considered that species of Azteca are insectivorous, and reported them feeding on dead termites and crickets; these investigators did not observe them foraging on raw meat. Because the baits in our traps were not fresh throughout the whole study, we presume that their putrefied odor may have attracted Azteca workers.

Species of Azteca nest in trees, usually in hollow branches or building carton nests inside or outside branches. All arboreal Azteca species construct "carton shelves" inside internodes, where the ants store their immatures [20].

Very little is known about the life history of American Dolichoderus [21]. According to Johnson [22], this genus can nest in trees (hollow and live stems and branches) and can feed on decomposing animal matter [23], which could have improved the likelihood of finding it in the traps that we used. Dolichoderus is one of the most exudate-dependent genera, and the amino acids obtained from the hemolymph of trophobionts may provide a more-balanced larval food supply [18]. Fowler et al. [24] stated that this genus feeds on liquids of undetermined nature (possibly from floral and extrafloral nectaries and/or honeydew). We suggest that members of the genus could feed on exudates from vertebrate remains rather than on the carcass itself.

Cephalotes (= Zacryptocerus) was previously collected in northern Venezuela from rat carcasses [25]. C. clypeatus was also collected from a mouse carcass during a field study conducted in a secondary forest in southeastern Brazil [8]. There are no definitive field studies on the diet of the arboreal genus Cephalotes, although it can be partially inferred from laboratory experiments, which indicate the consumption of decomposing animal matter (mainly freshly killed insects) [26]. Although Roche and Wheeler [27] included carcasses among the food items for Cephalotes texanus (Santschi), Cephalotes rohweri (Wheeler), and Cephalotes maculatus (Smith), these investigators did not specify whether the carcasses were of invertebrates or vertebrates.

Typically, the grouping of ant species into guilds is based mainly on criteria such as the morphology and type of nest [28-30]. In forensic entomology, the guilds of carrion insects are traditionally defined as necrophages, predators and parasitoids, omnivores, and adventive species [31]. According to Villet [32], this functional classification is intended to reflect the interest of forensic entomologists in defining the role of the organisms as sources of forensic evidence, rather than to provide an explicitly ecological approach. In this sense, classifying ants in the guild of omnivorous species may not accurately reflect the forensic importance of this group in some cases.

Some species of Azteca, Camponotus and Dolichoderus live mostly in trees (some of them exclusively) and are therefore included in the guild of arboreal ants [29]. Because the baits that we used were hung from trees, potential biases could arise from the natural tendency to collect predominantly species of this guild. It is unusual to find a dead human body in a tree (except in cases of hanging or airplane crashes in forest areas). If we had used a different methodology, we would have collected ant species from other guilds, e.g., those that forage on the soil.

The use of small amounts of decaying animal matter rather than entire carcasses as bait may have affected the outcome of the collections with regard to the abundance of individuals and richness of species, because of differences between these two types of resources in the amount of flesh and the number of available ecological niches.

It is unlikely that the observed differences in distribution of the ants among the different environments (Table 1) are due to diverse weather conditions, because all the municipalities have the same type of weather. Therefore, these differences are most likely attributable to other factors, such as intrinsic habitat features and the relative degree of disturbance in the forest areas from the different municipalities. For example, the nearly undisturbed forest area in Artur Nogueira showed the highest abundance of Dolichoderus among the forests in all municipalities. This is in agreement with Shattuck [33], who stated that well-preserved forest environments are the preferred environments for Dolichoderus. This association could also explain the low abundance of specimens of Dolichoderus in the urban settings. The relationship between abundance and degree of disturbance of forest areas was previously explored for carrion wasps [5].

The main objective of the present study was to collect flying insects (mainly flies and wasps) rather than ants, which accounts for the apparent inadequacy of the carrion traps that we used, designed for flying insects. However, the insistence by ants on crawling down the cord to access the traps, and their predation on other trapped insects attracted our attention, so we decided to collect ants. Actually, this 
predatory behavior was so intense that sometimes we only found fragments of other insects in the traps. This behavior may potentially lead to underestimation of the number of insects of forensic importance (mainly flies) in a given locality. Therefore, protecting the traps from ants (e.g., by coating the cord with lubrication oil) is advised when their influence is to be excluded.

Thorough investigations of the actual role of ants as cadaver consumers are still lacking. Aspects such as accurate determination of the rate of tissue removal from the carcass by these insects have never been studied in sufficient detail. Studies of this nature could deepen our understanding of the ecological importance of necrophagy for the ants, and also make some contribution to the expansion of our knowledge of their diet.

\section{CONFLICT OF INTEREST}

The authors confirm that this article content has no conflict of interest.

\section{ACKNOWLEDGEMENTS}

TCM has been supported by a scholarship from FAPESP (São Paulo Research Foundation), grant no. 06/60504-9. WACG has been partially supported by a grant from CNPq (The National Council for Scientific and Technological Development). The observations reported in this study are part of a Thematic Project named "Forensic Entomology: The utilization of Arthropods for determining time, place, cause, and circumstances of death", supported by FAPESP, grant no. 04/08544-0.

\section{DISCLAIMER}

Some data presented in this paper have been partially reported, in Portuguese, as an extended abstract, at the XVIII Simpósio de Mirmecologia, which took place in São Paulo in Nov 2007 (Moretti, T. C., Thyssen, P. J., Godoy, W. A. C.; Solis, D. R. Formigas coletadas durante investigações forenses no sudeste brasileiro. Biológico, 2007, 69 - suppl. $I I, 465-467)$. In the present paper, we extend the results previously presented, showing a complete data set, which stresses the importance of ants in a forensic scenario. The methods described in the present paper are similar to those described by Moretti et al. (2011), but are provided here for the sake of clarity and convenience.

\section{REFERENCES}

[1] Payne, J. A. A summer carrion study of the baby pig Sus scrofa Linnaeus. Ecology, 1965, 46, 592-602.

[2] Moretti, T. C.; Ribeiro, O. B.; Thyssen, P. J.; Solis, D. R. Insects on decomposing carcasses of small rodents in a secondary forest in southeastern Brazil. Eur. J. Entomol., 2008, 105, 691-696.

[3] Catts, E. P.; Haskell, N. H. Entomology and death: a procedural guide, Joyce's Print Shop, Inc.: Clemson, 1990.

[4] Campobasso, C. P.; Marchetti, D.; Introna, F.; Colonna, M. F. Postmortem artifacts made by ants and the effect of ant activity on decompositional rates. Am. J. Forensic Med. Pathol., 2009, 30, 8487.

[5] Moretti, T. C.; Giannotti, E.; Thyssen, P. J.; Solis, D. R.; Godoy, W. A. C. Bait and habitat preferences, and temporal variability of social wasps (Hymenoptera: Vespidae) attracted to vertebrate carrion. J. Med. Entomol., 2011, 48, 1069-1075.

[6] Wells, J. D.; Greenberg, B. Effect of the red imported fire ant (Hymenoptera: Formicidae) and carcass type on the daily occurrence of post feeding carrion-fly larvae (Diptera:
Calliphoridae, Sarcophagidae). J. Med. Entomol., 1994, 31, 171174.

[7] Early, M.; Goff, M. L. Arthropod succession patterns in exposed carrion on the island of $\mathrm{O}^{\prime}$ ahu, Hawaiian Islands, USA. J. Med. Entomol., 1986, 23, 520-531.

[8] Moretti, T. C.; Ribeiro, O. B. Cephalotes clypeatus Fabricius (Hymenoptera: Formicidae): nesting habits and occurrence in animal carcass. Neotrop. Entomol., 2006, 35, 412-415.

[9] Lindgren, N. K.; Bucheli, S. R.; Archambeault, A. D.; Bytheway, J. A. Exclusion of forensically important flies due to burying behavior by the red imported fire ant (Solenopsis invicta) in southeast Texas. Forensic Sci. Int., 2011, 204 (1-3), e1-e3.

[10] Anderson, G. S.; Vanlaerhoven, S. L. Initial studies on insect succession on carrion in southwestern British Columbia. $J$. Forensic Sci., 1996, 41, 617-625.

[11] Morellato, P. C.; Leitão Filho, H. F. Ecologia e preservação de uma floresta tropical urbana: reserva de Santa Genebra; Editora da UNICAMP: Campinas, 1995.

[12] Souza, A. M.; Linhares, A. X. Diptera and Coleoptera of potential forensic importance in Southeastern Brazil: relative abundance and seasonality. Med. Vet. Entomol., 1997, 11, 8-12.

[13] Bolton, B. Identification Guide to the Ant Genera of the World; Harvard University Press: Cambridge, 1994.

[14] Derraik, J. G. B.; Early, J. W.; Closs, G. P.; Dickinson, K. J. M. Morphospecies and taxonomic species comparison for Hymenoptera. J. Insect Sci., 2010, 10, 1-7 (article 108).

[15] Ulysséa M. A.; Cereto, C. E.; Rosumek, F. B.; Silva, R. R.; Lopes, B. C. Updated list of ant species (Hymenoptera, Formicidae) recorded in Santa Catarina State, southern Brazil, with a discussion of research advances and priorities. Rev. Bras. Entomol., 2011, 55, 603-611.

[16] Agosti, D.; Majer, J. D.; Alonso, L. E.; Schultz, T. R. Ants: Standard Methods for Measuring and Monitoring Biodiversity; Smithsonian Institution Press: Washington, 2000.

[17] Oliveira-Costa, J.; Blanc-Celino, T. In: Entomologia forense Quando os insetos são vestígios; J. Oliveira-Costa, Ed.; Millennium Editora: Campinas, 2011; pp. 251-282.

[18] Cook, S. C.; Davidson, D. W. Nutritional and functional biology of exudate-feeding ants. Entomol. Exp. Appl., 2006, 118, 1-10.

[19] Cabrera, M.; Jaffé, K. A trophic mutualism between the myrmecophytic Melastomataceae Tococa guianensis Aublet and an Azteca ant species. Ecotropicos, 1994, 7, 1-10.

[20] Vieira, A. S.; Faccenda, O.; Antonialli-Junior, W. F.; Fernandes, W. D. Nest structure and occurrence of three species of Azteca (Hymenoptera, Formicidae) in Cecropia pachystachya (Urticaceae) in non-floodable and floodable pantanal areas. Rev. Bras. Entomol., 2010, 54, 441-445.

[21] Ortius, D. A Dolichoderus taschenbergi queen found in a polygynous colony of D. plagiatus (Hymenoptera: Formicidae). Psyche, 1995, 102, 147-150.

[22] Johnson, C. Identification and nesting sites of North American species of Dolichoderus Lund (Hymenoptera: Formicidae). Insecta Mundi, 1989, 3, 1-9.

[23] Clark, J. The Australian ants of the genus Dolichoderus (Formicidae). Subgenus Hypoclinea Mayr. Aust. Zool., 1930, 6, 252-268.

[24] Fowler, H. G.; Forti, L. C.; Brandão, C. R. F.; Delabie, J. C.; Vasconcelos, H. L. In Ecologia nutricional de insetos e suas implicações no manejo de pragas; A. R. Panizzi and J. R. P. Parra, Eds.; Manole: São Paulo, 1991; pp. 131-223.

[25] Velásquez, Y. A checklist of arthropods associated with rat carrion in a montane locality of northern Venezuela. Forensic Sci. Int., 2008, 174, 67-69.

[26] Wilson, E. O. A social ethogram of the Neotropical arboreal ant Zacryptocerus varians (Fr. Smith). Anim. Behav., 1976, 24, 354363.

[27] Roche, R. K.; Wheeler, D. E. Morphological specializations of the digestive tract of Zacryptocerus rohweri (Hymenoptera: Formicidae). J. Morphol., 1997, 234, 253-262.

[28] Delabie, J. H. C.; Agosti, D.; Nascimento, I. C. In: Sampling ground-dwelling ants: case studies from the world's rain forests; D. Agosti, J. D. Majer, L. E. Alonso and T. R. Schultz, Eds.; Curtin University, School of Environmental Biology: Perth, 2000; pp. 117.

[29] Silvestre, R.; Brandão, C. R. F.; Silva, R. R. In: Introducción a las hormigas de la región Neotropical; F. Fernández, Eds.; Instituto de 
Investigación de Recursos Biológicos Alexander von Humboldt: Bogotá, 2003; pp. 113-148.

[30] Macedo, L. P. M.; Berti Filho, E.; Delabie, J. H. C. Epigean ant communities in Atlantic Forest remnants of São Paulo: a comparative study using the guild concept. Rev. Bras. Entomol., 2011, 55, 75-78.

[31] Byrd, J. H.; Castner, J. L. Forensic Entomology: the Utility of Arthropods in Legal Investigations; CRC Press: Boca Raton, 2010.
[32] Villet, M. H. African carrion ecosystems and their insect communities in relation to forensic entomology. Pest Technol., 2011, 5, 1-15.

[33] Shattuck, S. O. Generic revision of the ant subfamily Dolichoderinae (Hymenoptera: Formicidae). Sociobiology, 1992, 21, 1-181.

(C) Moretti et al.; Licensee Bentham Open.

This is an open access article licensed under the terms of the Creative Commons Attribution Non-Commercial License (http://creativecommons.org/licenses/by$\mathrm{nc} / 3.0 /$ ) which permits unrestricted, non-commercial use, distribution and reproduction in any medium, provided the work is properly cited. 